Check for updates

Cite this: RSC Adv., 2018, 8, 23990

Received 23rd May 2018

Accepted 27th June 2018

DOI: $10.1039 / c 8 r a 04375 b$

rsc.li/rsc-advances

\section{Diastereoselective synthesis of dispirooxindoles via [3+2] cycloaddition of azomethine ylides to 3- phenacylideneoxindoles and evaluation of their cytotoxicity $\dagger$}

\author{
Ying Huang, ${ }^{\text {ab }}$ Yi-Xin Huang, ${ }^{b}$ Jing Sun ${ }^{a}$ and Chao-Guo Yan (D) *a
}

\begin{abstract}
The three-component reaction of 1,2,3,4-tetrahydroisoquinoline, isatins and 3-phenacylideneoxindoles in refluxing ethanol afforded dispiro[indoline-3,1'-pyrrolo[2,1-a]isoquinoline- $3^{\prime}, 3^{\prime}$-indolines] $(4 a-4 x)$ in good yields via 1,3-dipolar cycloaddition of in situ generated azomethine ylide with the exocyclic double bond of 3-phenacylideneoxindoles. ${ }^{1} \mathrm{H}$ NMR spectra and single crystal structures indicated the reaction has high regioselectivity and diastereoselectivity. Furthermore, their biological activities have been preliminarily demonstrated by in vitro evaluation against mouse breast cancer cells 4T1 and human liver cancer cells HepG2 by MTT assay. The results demonstrated that some of the compounds showed cytotoxicities to cell lines of 4T1 and HepG2, and indicated that novel spirooxindoles may become potential lead compounds for further biological screenings of their medicinal applications.
\end{abstract}

\section{Introduction}

The spirooxindole core is one of the most privileged heterocyclic rings, which not only exists in a number of naturally occurring substances, but also is featured in many medicinally relevant compounds with wide biological applications. ${ }^{1,2}$ Among various carbocyclic and heterocyclic spirooxindole systems, spiropyrrolidinyl oxindoles are frequently encountered in natural alkaloids and are often considered as attractive templates for drug discovery. ${ }^{3}$ Spiropyrrolidinyl oxindole is the spiro ring fusioning at the 3 -position of the oxindole core with various substitutions around the pyrrolidine and oxindole rings. Some of them exhibit significant bioactivities such as horsfiline, strychnofoline, spirotryprostatin A and palmirine ${ }^{4}$ (Fig. 1). Apart from natural oxindole alkaloids, synthesized spiropyrrolidinyl oxindoles have been widely studied for their antiviral, antibacterial and anti-cancer activities. ${ }^{5,6}$ Their remarkable pharmacological activity and unique molecular architecture have made spiropyrrolidinyl oxindoles and their derivatives attractive synthetic targets. As a consequence, many efficient synthetic procedures have been developed for the preparation of the diversely structural spiropyrrolidinyl oxindoles. ${ }^{7}$

1,3-Dipolar cycloaddition reaction is an efficient and highyielding, regio- and stereo controlled method for the synthesis

${ }^{a}$ College of Chemistry \& Chemical Engineering, Yangzhou University, Yangzhou 225002, China.E-mail: cgyan@yzu.edu.cn

${ }^{b}$ College of Medicine, Yangzhou University, Yangzhou 225001, China

$\dagger$ Electronic supplementary information (ESI) available: ${ }^{1} \mathrm{H}$ and ${ }^{13} \mathrm{C}$ NMR spectra for all new compounds. CCDC 1556207-1556209. For ESI and crystallographic data in CIF or other electronic format see DOI: $10.1039 / \mathrm{c} 8 \mathrm{ra} 04375 \mathrm{~b}$ of heterocyclic compounds. For the preparation of fivemembered nitrogen-containing cyclic compounds, in particular pyrrolidines, dihydropyrroles, and pyrroles, [3+2] cycloaddition of azomethine ylides with alkenes is very effective and has been studied widely. ${ }^{\mathbf{8} 9}$ If the azomethine ylides are generated from isatin derived compounds and $\alpha$-amino acids through the thermal decarboxylation, pyrrolidine-containing spirooxindoles with high regioselectivity and stereoselectivity will be obtained. ${ }^{\mathbf{1 0 , 1 1}}$

Heteroaromatic $\mathrm{N}$-ylides such as pyridinium, thiazolium, quinolinium, isoquinolinium methylides which are readily available from the alkylation of azaaromatic heterocycles and sequential deprotonation reaction have also been used as one kind of reactive azomethine ylides extensively in cycloadditions for the synthesis of the fused heterocycles with a nitrogen at the point of fusion. ${ }^{12}$ Our group had reported the green synthetic methods for complex heterocyclic compounds, such as efficient synthesis of spiro[indoline-3,1'-pyrrolo[2,1-a]isoquinolines via 1,3-cycloaddition reactions of 3-phenacylideneoxindoles with aza-aromatic N-ylides generated from isoquinolinium salts. ${ }^{13}$ Wang's group synthesized some analogues by using 3,4-dihydroisoquinolinium salts. ${ }^{\mathbf{1 4}}$ In addition, the 1,3-dipolar

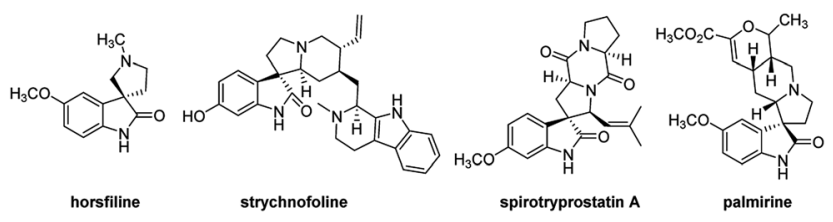

Fig. 1 Representative spiropyrrolidinyl oxindole alkaloids. 


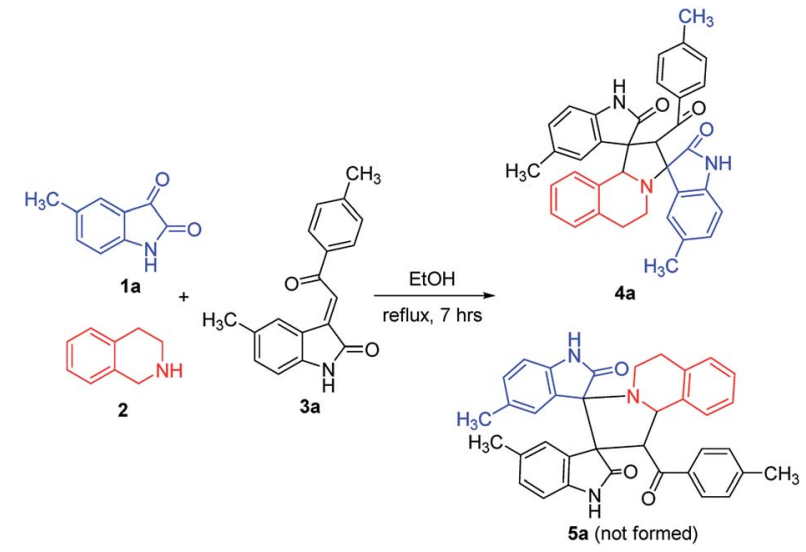

Scheme 1 Three-component reaction for dispirooxindole $4 a$.

cycloaddition reactions of isatin, benzylamine and chalcone derivatives or benzylideneacetones are reported, in which azomethine ylides are in situ generated from isatin and benzylamine. ${ }^{15}$ Using 1,2,3,4-tetrahydroisoquinoline instead of benzylamine, the spiro compounds with key structure of spiro [indoline-3,1'-pyrrolo[2,1-a]isoquinolines could be obtained. ${ }^{16}$ In this paper, we wish to report an efficient 1,3-dipolar cycloaddition reaction of isatins, 1,2,3,4-tetrahydroisoquinoline and 3-phenacylideneoxindoles for regioselective and diastereoselective synthesis of novel functionalized spirooxindoles. Additionally, their biological activities have been preliminarily demonstrated by in vitro evaluation against mouse breast cancer cells $4 \mathrm{~T} 1$ and human liver cancer cells HepG2 by MTT assay.

\section{Results and discussions}

\subsection{Synthesis of dispirooxindole derivatives}

According to previously established reaction conditions for the domino reactions for the efficient synthesis of the functionalized spiro[indoline-3, $1^{\prime}$-pyrrolo[2,1-a] isoquinolines, ${ }^{13}$ we have started the reaction of 5-methylisatin (1a), 1,2,3,4-tetrahydroisoquinoline

Table 1 Three-component reaction for synthesis of spirooxindoles $4 a-x^{a}$

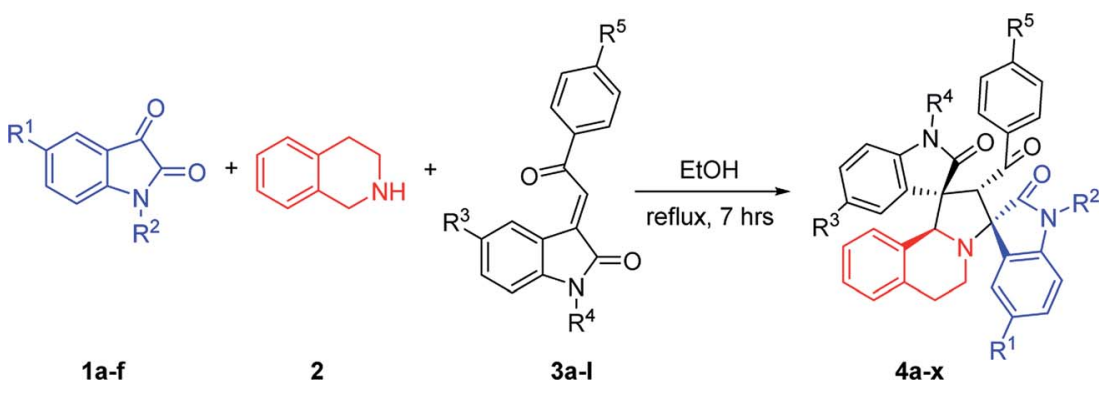

\begin{tabular}{|c|c|c|c|c|c|c|c|}
\hline Entry & Compd & $\mathrm{R}^{1}$ & $\mathrm{R}^{2}$ & $\mathrm{R}^{3}$ & $\mathrm{R}^{4}$ & $\mathrm{R}^{5}$ & Yield $^{b}(\%)$ \\
\hline 1 & $4 a$ & $\mathrm{CH}_{3}$ & $\mathrm{H}$ & $\mathrm{CH}_{3}$ & $\mathrm{H}$ & $\mathrm{CH}_{3}$ & 70 \\
\hline 2 & $4 b$ & $\mathrm{CH}_{3}$ & $\mathrm{H}$ & $\mathrm{Cl}$ & $\mathrm{H}$ & $\mathrm{OCH}_{3}$ & 76 \\
\hline 3 & $4 c$ & $\mathrm{Cl}$ & $\mathrm{H}$ & $\mathrm{CH}_{3}$ & $\mathrm{H}$ & $\mathrm{CH}_{3}$ & 81 \\
\hline 4 & $4 d$ & $\mathrm{CH}_{3}$ & $\mathrm{H}$ & $\mathrm{H}$ & $\mathrm{H}$ & $\mathrm{H}$ & 90 \\
\hline 5 & $4 e$ & $\mathrm{CH}_{3}$ & $\mathrm{H}$ & $\mathrm{CH}_{3}$ & $\mathrm{H}$ & $\mathrm{Cl}$ & 80 \\
\hline 6 & $4 \mathrm{f}$ & $\mathrm{CH}_{3}$ & $\mathrm{H}$ & $\mathrm{Cl}$ & $\mathrm{H}$ & $\mathrm{CH}_{3}$ & 50 \\
\hline 7 & $4 g$ & $\mathrm{Cl}$ & $\mathrm{H}$ & $\mathrm{CH}_{3}$ & $\mathrm{H}$ & $\mathrm{Cl}$ & 82 \\
\hline 8 & $4 h$ & $\mathrm{Cl}$ & $\mathrm{H}$ & $\mathrm{Cl}$ & $\mathrm{H}$ & $\mathrm{OCH}_{3}$ & 67 \\
\hline 9 & $4 \mathrm{i}$ & $\mathrm{Cl}$ & $\mathrm{H}$ & $\mathrm{F}$ & $\mathrm{H}$ & $\mathrm{CH}_{3}$ & 57 \\
\hline 10 & $4 j$ & $\mathrm{CH}_{3}$ & $\mathrm{H}$ & $\mathrm{Cl}$ & $\mathrm{CH}_{2} \mathrm{Ph}$ & $\mathrm{Cl}$ & 57 \\
\hline 11 & $4 k$ & $\mathrm{CH}_{3}$ & $\mathrm{H}$ & $\mathrm{H}$ & $\mathrm{CH}_{2} \mathrm{Ph}$ & $\mathrm{H}$ & 58 \\
\hline 12 & 41 & $\mathrm{CH}_{3}$ & $\mathrm{H}$ & $\mathrm{CH}_{3}$ & $\mathrm{CH}_{2} \mathrm{Ph}$ & $\mathrm{CH}_{3}$ & 62 \\
\hline 13 & $4 m$ & $\mathrm{CH}_{3}$ & $\mathrm{H}$ & $\mathrm{CH}_{3}$ & $\mathrm{CH}_{2} \mathrm{Ph}$ & $\mathrm{Cl}$ & 66 \\
\hline 14 & $4 n$ & $\mathrm{CH}_{3}$ & $\mathrm{H}$ & $\mathrm{CH}_{3}$ & $\mathrm{C}_{4} \mathrm{H}_{9}$ & $\mathrm{CH}_{3}$ & 90 \\
\hline 15 & 40 & $\mathrm{Cl}$ & $\mathrm{H}$ & $\mathrm{Cl}$ & $\mathrm{C}_{4} \mathrm{H}_{9}$ & $\mathrm{CH}_{3}$ & 72 \\
\hline 16 & $4 p$ & $\mathrm{H}$ & $\mathrm{CH}_{3}$ & $\mathrm{CH}_{3}$ & $\mathrm{H}$ & $\mathrm{CH}_{3}$ & 85 \\
\hline 17 & $4 q$ & $\mathrm{H}$ & $\mathrm{CH}_{3}$ & $\mathrm{Cl}$ & $\mathrm{H}$ & $\mathrm{CH}_{3}$ & 63 \\
\hline 18 & $4 r$ & $\mathrm{H}$ & $\mathrm{CH}_{3}$ & $\mathrm{CH}_{3}$ & $\mathrm{CH}_{2} \mathrm{Ph}$ & $\mathrm{Cl}$ & 58 \\
\hline 19 & $4 s$ & $\mathrm{CH}_{3}$ & $\mathrm{CH}_{2} \mathrm{Ph}$ & $\mathrm{CH}_{3}$ & $\mathrm{H}$ & $\mathrm{CH}_{3}$ & 79 \\
\hline 20 & $4 t$ & $\mathrm{CH}_{3}$ & $\mathrm{CH}_{2} \mathrm{Ph}$ & $\mathrm{Cl}$ & $\mathrm{H}$ & $\mathrm{OCH}_{3}$ & $80^{c}$ \\
\hline 21 & $4 u$ & $\mathrm{CH}_{3}$ & $\mathrm{CH}_{2} \mathrm{Ph}$ & $\mathrm{Cl}$ & $\mathrm{H}$ & $\mathrm{CH}_{3}$ & $62^{d}$ \\
\hline 22 & $4 v$ & $\mathrm{Cl}$ & $\mathrm{CH}_{2} \mathrm{Ph}$ & $\mathrm{Cl}$ & $\mathrm{H}$ & $\mathrm{CH}_{3}$ & 76 \\
\hline 23 & $4 w$ & $\mathrm{CH}_{3}$ & $\mathrm{CH}_{2} \mathrm{Ph}$ & $\mathrm{CH}_{3}$ & $\mathrm{CH}_{2} \mathrm{Ph}$ & $\mathrm{Cl}$ & 60 \\
\hline 24 & $4 x$ & $\mathrm{Cl}$ & $\mathrm{C}_{4} \mathrm{H}_{9}$ & $\mathrm{CH}_{3}$ & $\mathrm{H}$ & $\mathrm{CH}_{3}$ & 50 \\
\hline
\end{tabular}

${ }^{a}$ Reaction conditions: isatin $(0.30 \mathrm{mmol})$, tetrahydroisoquinoline $(0.30 \mathrm{mmol}), 3$-phenacylideneoxindole $(0.25 \mathrm{mmol})$; reflux, $7 \mathrm{~h} .{ }^{b}$ Isolated yields.

${ }^{c}$ Ratio of $\mathbf{4 t}: \mathbf{4}^{\prime} \mathbf{t}=90: 10 .{ }^{d}$ Ratio of $\mathbf{4} \mathbf{u}: \mathbf{4}^{\prime} \mathbf{u}=75: 25$. 
(2) and 5-methyl-3-p-methylphenacylideneoxindole (3a) in a onepot, three-component procedure depicted in Scheme 1. After refluxing the mixture of substrates in ethanol for about seven hours, it was pleased to find that the resulting precipitates were collected by filtration and characterized as the expected dispiro [indoline-3, $1^{\prime}$-pyrrolo[2,1-a]isoquinoline- $3^{\prime}, 3^{\prime}$-indoline] (4a) in $70 \%$ yield, in which the two scaffold of oxindolines exist on the 1,3-positions in the newly formed pyrrolidinyl ring. It should be pointed out that the isomeric product 5a, in which the two scaffold of oxindolines were connected together, was not formed in the reaction. This results also indicated this three-component reaction has high regioselectivity. Therefore, the expected threecomponent reaction successfully proceeded in very simple reaction conditions without adding other catalyst. When other solvent such as methanol, acetonitrile and toluene was used, the yield of the product (4a) was decreased.

Then, we extended the scope to the reaction under this simple reaction conditions. Various isatins (1a-f) and 3-phenacylideneoxindoles (3a-1) with both electron-withdrawing and electron releasing-substituents were employed in the threecomponent reaction under same conditions. The corresponding novel dispirooxindoles (4b-x) were successfully synthesized in high yields. The substituents on the both oxindoles showed little effect on the yields of the products. The results are summarized in Table 1. It should be pointed out that the pure products were usually obtained by filtration of the formed precipitates. The products were fully characterized by the spectroscopic methods. For examples, the IR spectrum of 4 a showed three peaks of the carbonyl groups at 1725, 1676, $1626 \mathrm{~cm}^{-1}$. Because there are four chiral carbon atoms in the newly formed ring of pyrrolidine, several diastereoisomers might be formed in the 1,3-dipolar cycloaddition reaction. In the ${ }^{1} \mathrm{H}$ NMR spectrum of $4 \mathrm{a}$, two singlets appeared at $\delta 5.59$ and $\delta 4.89 \mathrm{ppm}$ were the signs of two cyclic $\mathrm{CH}$ unit in newly-formed pyrrolidine, and the two characteristic signals appeared at $\delta 10.38$ and $\delta 10.34$ ppm were the corresponding signs of $\mathrm{NH}$ protons in two oxindole rings. This result clearly showed that only one diastereoisomer existed in the obtained product. $\operatorname{In}{ }^{13} \mathrm{C}$ NMR spectrum of $\mathbf{4 a}$, the two carbonyl group of the oxindole ring showed signs at $\delta 179.1$ and $177.4 \mathrm{ppm}$, and the carbonyl group in benzoyl group showed sign at $\delta 196.1 \mathrm{ppm}$. The mass spectrum displayed a distinguished peak at $m / z 554.2447$ which further supported the formation of cycloadduct 4a. Other spiro compounds also displayed similar spectroscopy. But the ${ }^{1} \mathrm{H}$ and

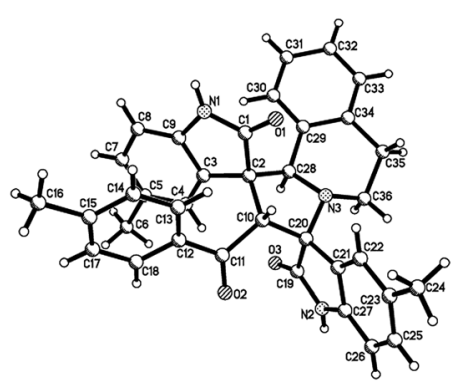

Fig. 2 Single crystal structure of compound $4 a$.

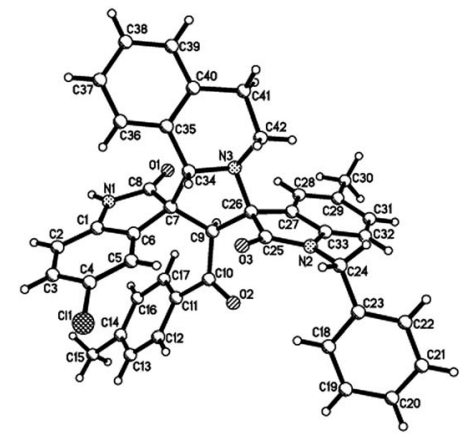

Fig. 3 Single crystal structure of compound $4 u$.

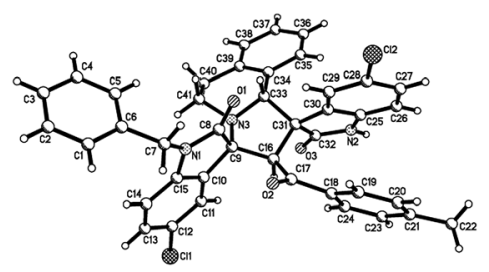

Fig. 4 Single crystal structure of compound $4 \mathrm{v}$.

${ }^{13} \mathrm{C}$ NMR of the compounds $\mathbf{4 t}$ and $\mathbf{4 u}$ clearly indicated two diastereoisomers existed in the obtained samples. The major/ minor ratios of $\mathbf{4 t} / \mathbf{4} \mathbf{t}^{\prime}(90: 10)$ and $\mathbf{4} \mathbf{u} / \mathbf{4 \mathbf { u } ^ { \prime }}$ (75:25) were determined by integral of signs in the ${ }^{1} \mathrm{H}$ NMR spectra. For determining the relative configuration of the spiro compounds 4 $\mathbf{4 x}$, the single crystal structures of three compounds $\mathbf{4 a}, \mathbf{4} \mathbf{u}$ and 4v (Fig. 2, 3 and 4) were successfully determined by X-ray diffraction. From the figures, it is clearly seen that the three single crystal structures have same relative configuration, in which two oxindole units existed at trans-position. The two protons in the ring of pyrrolidine also existed in trans-configuration. On the basis of NMR spectra and single crystal structures, we can concluded that this three-component reaction predominately give this kind of the diastereoisomer as major product and the other diastereoisomers were formed as minor product in few cases.

\subsection{Viability of two cancer cells of compounds $4 a-4 x$}

All newly synthesized compounds were subjected to a preliminary evaluation on their in vitro cytotoxic activity, which was represented as the inhibition rate of the tested compounds to mouse breast cancer cells $4 \mathrm{~T} 1$ and human liver cancer cells HepG2 at the concentration of $200 \mu \mathrm{g} \mathrm{mL}{ }^{-1}$. The cytotoxic activity to $4 \mathrm{~T} 1$ cells was not good as we expected. Among the tested compounds $\mathbf{4}$, compound $\mathbf{4 i}\left(\mathrm{R}^{3}=\mathrm{F}\right)$ displayed highest cytotoxic activity to HepG2 cells with the inhibition rate of $73.50 \%$, followed by $4 \mathbf{h}\left(\mathrm{R}^{3}=\mathrm{Cl}\right)$ and $\mathbf{4 d}\left(\mathrm{R}^{3}=\mathrm{H}\right)$ (Table 2$)$. Then the inhibition rate of human liver cancer cells line HepG2 of these three compounds were tested at three concentrations of 50, 100 and $200 \mu \mathrm{g} \mathrm{mL}^{-1}$ (Table 3).

In detail, compounds $\mathbf{4 a - 4 i}$ which have no substituents on $\mathrm{N}$ atom of isatin $\left(\mathrm{R}^{2}=\mathrm{H}\right)$ and 3-phenacylideneoxindole $\left(\mathrm{R}^{4}=\mathrm{H}\right)$ 
Table 2 Preliminary evaluation on the anticancer activities of synthesized compounds $4 \mathrm{a}-\mathrm{x}$ on $4 \mathrm{~T} 1$ and HepG2 cancer cell lines $\left(200 \mu \mathrm{g} \mathrm{mL}{ }^{-1}\right)^{a}$

\begin{tabular}{|c|c|c|c|c|c|c|c|c|}
\hline & \multicolumn{4}{|c|}{$4 \mathrm{~T} 1$ cell death } & \multicolumn{4}{|c|}{ HepG2 cell death } \\
\hline & \multicolumn{2}{|l|}{$24 \mathrm{~h}$} & \multicolumn{2}{|l|}{$48 \mathrm{~h}$} & \multicolumn{2}{|l|}{$24 \mathrm{~h}$} & \multicolumn{2}{|l|}{$48 \mathrm{~h}$} \\
\hline $4 a$ & 2.31 & $0.915 \pm 0.011$ & 25.80 & $0.870 \pm 0.015$ & 2.84 & $0.868 \pm 0.024$ & 32.86 & $0.506 \pm 0.004$ \\
\hline $4 b$ & 2.23 & $0.916 \pm 0.016$ & 15.05 & $0.984 \pm 0.014$ & 3.99 & $0.858 \pm 0.023$ & 19.34 & $0.591 \pm 0.110$ \\
\hline $4 e$ & 7.88 & $0.863 \pm 0.022$ & 20.64 & $0.925 \pm 0.060$ & 2.97 & $0.867 \pm 0.014$ & 13.27 & $0.629 \pm 0.058$ \\
\hline $4 \mathbf{f}$ & 6.45 & $0.876 \pm 0.012$ & 19.43 & $0.937 \pm 0.098$ & 4.59 & $0.853 \pm 0.013$ & 14.22 & $0.623 \pm 0.045$ \\
\hline $4 g$ & 1 & $0.940 \pm 0.061$ & 27.64 & $0.851 \pm 0.034$ & 3.71 & $0.861 \pm 0.012$ & 23.16 & $0.567 \pm 0.056$ \\
\hline $4 \mathrm{~h}$ & 5.23 & $0.887 \pm 0.045$ & 23.25 & $0.896 \pm 0.137$ & 6.12 & $0.839 \pm 0.013$ & 70.11 & $0.098 \pm 0.006$ \\
\hline $4 \mathbf{i}$ & 10.38 & $0.839 \pm 0.025$ & 33.31 & $0.791 \pm 0.068$ & 5.34 & $0.846 \pm 0.028$ & 73.50 & $0.088 \pm 0.004$ \\
\hline $4 \mathrm{j}$ & 3.42 & $0.904 \pm 0.020$ & 17.87 & $0.954 \pm 0.051$ & 5.02 & $0.849 \pm 0.019$ & 25.25 & $0.554 \pm 0.066$ \\
\hline 40 & 0.23 & $1.370 \pm 0.021$ & 12.69 & $1.211 \pm 0.020$ & 1 & $1.208 \pm 0.030$ & 1 & $1.441 \pm 0.229$ \\
\hline $4 p$ & I & $1.377 \pm 0.011$ & 22.86 & $1.070 \pm 0.040$ & I & $1.180 \pm 0.028$ & I & $1.393 \pm 0.424$ \\
\hline $4 q$ & I & $1.514 \pm 0.009$ & 4.65 & $1.322 \pm 0.018$ & 23.9 & $0.897 \pm 0.022$ & 9.88 & $1.118 \pm 0.137$ \\
\hline $4 r$ & l & $1.402 \pm 0.027$ & 5.11 & $1.316 \pm 0.021$ & I & $1.217 \pm 0.018$ & I & $1.285 \pm 0.113$ \\
\hline $4 s$ & l & $1.376 \pm 0.016$ & 8.20 & $1.273 \pm 0.007$ & l & $1.292 \pm 0.025$ & 7.23 & $1.151 \pm 0.048$ \\
\hline $4 t$ & 1 & $1.481 \pm 0.016$ & / & $1.465 \pm 0.028$ & 1 & $1.385 \pm 0.020$ & 10.09 & $1.115 \pm 0.069$ \\
\hline $4 u$ & 2.75 & $1.108 \pm 0.039$ & / & $1.131 \pm 0.001$ & 2.75 & $1.117 \pm 0.154$ & & $1.053 \pm 0.019$ \\
\hline $4 v$ & I & $1.125 \pm 0.065$ & I & $1.211 \pm 0.021$ & 1 & $1.172 \pm 0.018$ & 1 & $1.036 \pm 0.010$ \\
\hline $4 w$ & 2.40 & $1.187 \pm 0.060$ & 5.249 & $1.197 \pm 0.005$ & 2.40 & $1.121 \pm 0.038$ & 5.25 & $0.947 \pm 0.026$ \\
\hline $4 x$ & 1 & $1.185 \pm 0.033$ & 1 & $1.201 \pm 0.002$ & l & $1.194 \pm 0.042$ & / & $1.314 \pm 0.110$ \\
\hline
\end{tabular}

inhibited the growth of HepG2 cells at the concentration of 200 $\mu \mathrm{g} \mathrm{mL}^{-1}$, displayed promising cytotoxicity to HepG2 cells with inhibition rates varying from $13.27 \%$ to $73.50 \%$. These results were much better than the other compounds $(\mathbf{4} \mathbf{j}-\mathbf{4 x})$ which have $\mathrm{N}$-substituents such as $\mathrm{CH}_{3}, \mathrm{C}_{4} \mathrm{H}_{9}$ and $\mathrm{CH}_{2} \mathrm{Ph}$. Compounds $\mathbf{4 j}-\mathbf{4 x}$ tend to precipitate out during the dilution process. These results would suggest that the polarity or lipo-hydro partition coefficient $(\log P)$ of the compound has a significant effect on its activity (Table 2).

As shown in Fig. 5, untreated cells exhibit regular blue colour. In contrast, cells treated with $\mathbf{4 i}$ at the concentration of $200 \mu \mathrm{g} \mathrm{mL} \mathrm{m}^{-1}$ showed clear red colour. It indicated that large amount of HepG2 cells died after treatment with 4i. Compounds $\mathbf{4 d}, \mathbf{4 h}$ and $\mathbf{4 i}$ showed a tendency of concentration-dependent cytotoxicity because their inhibition rates were greatly enhanced with increasing concentration. Among them, compound $\mathbf{4 i}\left(\mathrm{R}^{3}=\mathrm{F}\right)$ was the most powerful to inhibit the growth of HepG2 cells to $44.08 \%$ at the concentration of $50 \mu \mathrm{g} \mathrm{mL}^{-1}$ (Table 3 ). The cytotoxicity of compounds $\mathbf{4 d}, \mathbf{4 h}$ and $\mathbf{4 i}$ was tested on $3 \mathrm{~T} 3$ cells at the concentration of $200 \mu \mathrm{g} \mathrm{mL}{ }^{-1}$, the results showed that their cytocompatibility were good, which meant that they have cytotoxicity to cancer cells and were not toxic to normal cells (Fig. 6).

Table 3 Preliminary evaluation on the anticancer activities of $4 \mathrm{~d}, 4 \mathrm{~h}$ and $4 \mathrm{i}$ on HepG2 cancer cell lines

\begin{tabular}{|c|c|c|c|c|c|c|}
\hline \multirow{2}{*}{ Compound } & \multicolumn{2}{|c|}{$200 \mu \mathrm{g} \mathrm{mL}^{-1}$} & \multicolumn{2}{|c|}{$100 \mu \mathrm{g} \mathrm{mL}^{-1}$} & \multicolumn{2}{|c|}{$50 \mu \mathrm{g} \mathrm{mL} L^{-1}$} \\
\hline & \multicolumn{2}{|c|}{ Cell death } & \multicolumn{2}{|c|}{ Cell death } & \multicolumn{2}{|c|}{ Cell death } \\
\hline 4d & 67.40 & $0.325 \pm 0.018$ & 30.93 & $0.691 \pm 0.062$ & 16.12 & $0.838 \pm 0.040$ \\
\hline $4 h$ & 59.74 & $0.402 \pm 0.014$ & 30.64 & $0.693 \pm 0.028$ & 20.57 & $0.794 \pm 0.028$ \\
\hline
\end{tabular}



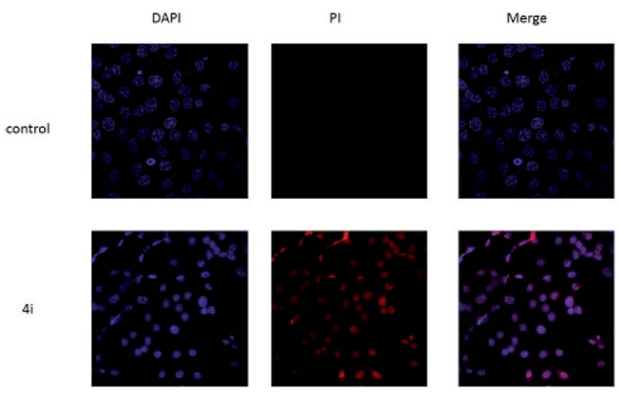

Fig. 5 The morphological features of survival status were monitored by fluorescence microscopy after staining with DAPI.

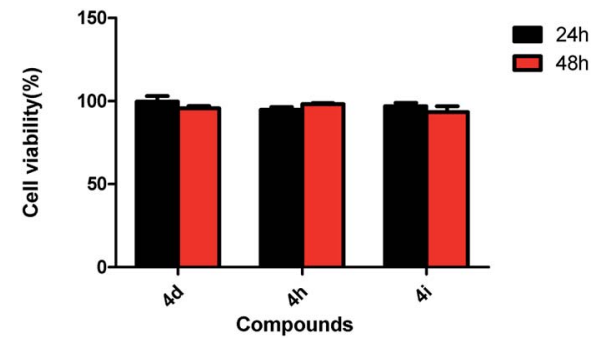

Fig. 6 Effect of compound 4d, 4 h and $4 \mathrm{i}$ on 3 T3 cell viabilities (200 $\mu \mathrm{g} \mathrm{mL}{ }^{-1}$ ).

\section{Conclusions}

In summary, we have developed an efficient strategy for the synthesis of complex spiro compounds by a 1,3-dipolar cycloaddition of 3-methyleneoxindoles with 1,2,3,4-tetrahydroisoquinoline and isatin derivatives. This three-component reaction afforded the anticipated spirooxindoles in excellent yields with high regio- and stereoselectivity. This synthetic protocol has advantages of mild reaction conditions, easily accessible starting materials and easy purification of the products, which makes it a useful and attractive method for the synthesis of the complex spiro heterocycles in synthetic and medicinal chemistry. Furthermore, the bioactivity detection of these spirooxindoles has led to the discovery of three compounds with promising cytotoxicity to HepG2 cells. The preliminary bioassay of these compounds will enlighten further structural modification and bioactivity studies on spirooxindoles for their medicinal applications.

\section{Experimental}

\subsection{Chemistry}

All reactions were performed in open atmosphere unless stated. All reagents, unless otherwise indicated, were obtained from commercial sources. ${ }^{1} \mathrm{H}$ and ${ }^{13} \mathrm{C}$ NMR spectra were recorded on a Bruker AV-600 instrument or Variance 400 spectrometer with DMSO- $d_{6}$ or $\mathrm{CDCl}_{3}$ as solvent and tetramethylsailane (TMS) was used as internal standard ( $\delta$ in ppm). IR spectra were obtained on a Bruker Tensor 27 spectrometer (KBr disc). HRMS were recorded on a Bruker UHR-TOF maXis spectrometer. X-ray data were collected on a Bruker Smart APEX-2 diffractometer. Melting points were taken on a hot-plate microscope apparatus and were uncorrected.

\subsection{General procedure for the preparation of $4 a-4 x$}

A mixture of isatin ( $0.3 \mathrm{mmol}), 1,2,3,4$-tetrahydroisoquinoline (0.3 mmol), and 3-phenacylideneoxindole $(0.25 \mathrm{mmol})$ in ethanol $(10 \mathrm{~mL})$ was stirred at reflux for seven hours. After completion of the reaction, as indicated by TLC, the solid was separated by filtration, washed with cold ethanol and vacuum dried. In some cases, additional purification by TLC was necessary.

5,5" -Dimethyl-2'-(4-methylbenzoyl)- $6^{\prime}, 10 b^{\prime}$-dihydro-2' $H, 5^{\prime} H$ dispiro[indoline-3, $1^{\prime}$-pyrrolo[2,1- $a$ ] isoquinoline- $3^{\prime}, 3^{\prime}$-indoline]2,2 $2^{\prime \prime}$-dione (4a). White solid, 70\%, mp. 244-245 ${ }^{\circ} \mathrm{C} ;{ }^{1} \mathrm{H}$ NMR $(400$ MHz, DMSO- $\left.d_{6}\right) \delta: 10.38(\mathrm{~s}, 1 \mathrm{H}, \mathrm{NH}), 10.34$ (s, 1H, NH), 7.63 (s, 1H, ArH), 7.23 (s, 1H, ArH), 7.10-7.00 (m, 7H, ArH), 6.88 (brs, 1H, ArH), 6.82-6.77 (m, 2H, ArH), 6.36 (d, $J=7.6 \mathrm{~Hz}, 1 \mathrm{H}, \operatorname{ArH})$, $6.24(\mathrm{~d}, J=7.2 \mathrm{~Hz}, 1 \mathrm{H}, \mathrm{ArH}), 5.59(\mathrm{~s}, 1 \mathrm{H}, \mathrm{CH}), 4.89(\mathrm{~s}, 1 \mathrm{H}, \mathrm{CH})$, 2.86-2.78 (m, 2H, CH), 2.64-2.60 (m, $2 \mathrm{H}, \mathrm{CH}), 2.29\left(\mathrm{~s}, 3 \mathrm{H}, \mathrm{CH}_{3}\right)$, $2.21\left(\mathrm{~s}, 6 \mathrm{H}, \mathrm{CH}_{3}\right) ;{ }^{13} \mathrm{C} \mathrm{NMR}\left(150 \mathrm{MHz}, \mathrm{DMSO}-d_{6}\right) \delta: 196.1,179.1$, $177.4,142.7,141.1,139.1,135.2,134.5,134.2,130.4,130.3$, $130.2,129.9,128.7,128.5,127.2,126.9,126.3,126.1,125.4$, 124.8, 123.1, 109.1, 108.6, 70.6, 68.7, 66.1, 58.2, 41.4,29.3, 21.0, 20.9, 20.6; IR (KBr) $\nu: 3355,3170,3029,2916,2832,1725,1676$, 1626, 1607, 1574, 1494, 1428, 1373, 1341, 1296, 1248, 1202, 1166, 1042, 1008, 947, 905, 810, 756, $730 \mathrm{~cm}^{-1}$; MS (m/z): HRMS (ESI) calcd for $\mathrm{C}_{36} \mathrm{H}_{32} \mathrm{~N}_{3} \mathrm{O}_{3}\left([\mathrm{M}+\mathrm{H}]^{+}\right)$: 554.2438, found: 554.2447 .

\subsection{Biology}

Three cancer cell lines are obtained from experimental cell resource centre of Shanghai Institutes for Biological Sciences. The relative cell viability was recorded by a microplate reader (SYenergy 2). The cell death stain was imaged by laser scanning confocal microscopy (LSCM, TLS SP8 STED).

Cytotoxic evaluation of compounds $4 a-4 x$ to mouse breast cancer cells $4 \mathrm{~T} 1$ and human liver cancer cells HepG2.

Cell viability assay. The cell viability was measured by MTT assay. Mouse breast cancer cells 4T1, Human liver cancer cells HepG2 and Mouse fibroblasts cells 3T3 were separately cultured in DMEM medium containing $10 \%$ fetal bovine serum and $1 \%$ penicillin-streptomycin at $37{ }^{\circ} \mathrm{C}$ and $5 \% \mathrm{CO}_{2}$. For in vitro cytotoxicity assay, 4T1, HepG2 and 3T3 cells were seeded into 96-well plates at $8 \times 10^{3} /$ well until adherent and then incubated with various concentrations of $\mathbf{4 a - 4 x}$ for 24 and 48 h. Ten microliters of $5 \mathrm{mg} \mathrm{mL} \mathrm{mTT}^{-1}$ solution was then added into each well, followed by incubation for 24 and $48 \mathrm{~h}$ at $37{ }^{\circ} \mathrm{C}$ in the presence of $5 \% \mathrm{CO}_{2}$. At the end of the incubated time, $100 \mu \mathrm{L}$ of DMSO was added to dissolve the formazan crystals. Finally, the absorbance at $490 \mathrm{~nm}$ of each well was recorded by a microplate reader (SYenergy 2). The final cell viabilities were calculated by $\left[\mathrm{OD}_{\text {(tested compounds group) }} / \mathrm{OD}_{\text {(control group) }}\right] \times 100 \%$.

Cell death stain. To investigate the cell survival status, HepG2 cells $\left(1 \times 10^{5} /\right.$ well $)$ suspended in $1 \mathrm{~mL}$ of DMEM medium were seeded in a 24 -well plate with cell climbing slices on the bottom 
of the plate for $12 \mathrm{~h}$, and then incubated with $\mathbf{4 i}(\mathbf{4 h}, \mathbf{4 d})$ (the final concentration was $200 \mu \mathrm{g} \mathrm{mL}^{-1}$ ) at $37^{\circ} \mathrm{C}$ for $48 \mathrm{~h}$. The cells were then rinsed twice with $0.01 \%$ PBS, fixed with $4 \%$ paraformaldehyde for $15 \mathrm{~min}, 0.4 \%$ Triton for $5 \mathrm{~min}$ and stained with DAPI and PI for 10 min. After rinsing with PBS three times, cell climbing slices were placed on the glass slides and imaged by laser scanning confocal microscopy (LSCM, TLS SP8 STED).

\section{Conflicts of interest}

There are no conflicts to declare.

\section{Acknowledgements}

This work was financially supported by the National Natural Science Foundation of China (Grant No. 21572196) and the Priority Academic Program Development of Jiangsu Higher Education Institutions. We also thank Analysis and Test Centre of Yangzhou University and Translational Medicine Research Institute of Yangzhou University providing instruments for analysis.

\section{Notes and references}

1 (a) R. M. Williams and R. Cox, Acc. Chem. Res., 2003, 36, 127139; (b) A. B. Dounay and L. E. Overman, Chem. Rev., 2003, 103, 2945-2963; (c) M. Santos, Tetrahedron, 2014, 70, 97359757; (d) D. Q. Yu and H. M. Liu, Eur. J. Med. Chem., 2015, 97, 673-698; (e) N. Ye, H. Y. Chen, E. A. Wold, P. Y. Shi and J. Zhou, ACS Infect. Dis., 2016, 2, 382-392.

2 (a) S. B. Kotha, A. C. Deb, K. Lahiri and E. Manivannan, Synthesis, 2009, 2, 165-193; (b) B. M. Trost and M. K. Brennan, Synthesis, 2009, 18, 3003-3025; (c) N. R. Ball-Jones, J. J. Badillo and A. K. Franz, Org. Biomol. Chem., 2012, 10, 5165-5181; (d) G. S. Singh and Z. Y. Desta, Chem. Rev., 2012, 112, 6104-6155.

3 (a) Y. Y. Liu, H. Wang and J. P. Wan, Asian J. Org. Chem., 2013, 2, 374-386; (b) Z. Y. Cao, Y. H. Wang, X. P. Zeng and J. Zhou, Tetrahedron, 2014, 70, 2406-2415; (c) D. Q. Cheng, Y. Ishihara, B. Tan and C. B. Barbas, III, ACS Catal., 2014, 4, 743-762; (d) R. G. Redkin, V. V. Lipson and D. V. Atamanuk, Mol. Diversity, 2016, 20, 299-344.

4 (a) C. V. Galliford and K. A. Scheidt, Angew. Chem., Int. Ed., 2007, 46, 8748-8758; (b) Q. Z. Yu, P. Guo, J. Jian, Y. Y. Chen and J. Xu, Chem. Commun., 2018, 54, 1125-1128. 5 (a) M. M. M. Santos, Tetrahedron, 2014, 70, 9735-9757; (b) S. M. Wang, K. Ding, Y. P. Lu, N. C. Zaneta, S. Qiu, G. P. Wang, D. G. Qin and S. Sangjeev, WO 2006091646, 2006; (c) P. Ramesh, K. S. Rao, R. Trivedi and B. S. Kumar, RSC Adv., 2016, 6, 26546-26552.

6 (a) G. Bhaskar, Y. Arun, C. Balachandran, C. Saikumar and P. T. Perumal, Eur. J. Med. Chem., 2012, 51, 79-91; (b) B. Yu, D. Q. Yu and H. M. Liu, Eur. J. Med. Chem., 2015, 97, 673-698; (c) Y. Arun, K. Saranraj, C. Balachandran and P. T. Perumal, Eur. J. Med. Chem., 2014, 74, 50-64; (d) Y. J. Zheng, C. M. Tice and S. B. Singh, Bioorg. Med. Chem. Lett., 2014, 24, 3673-3682.
7 (a) T. Penaska, K. Ormandyova, M. Meciarova, J. Filob and R. Sebesta, New J. Chem., 2017, 41, 5506-5512; (b) X. Fang and C. J. Wang, Org. Biomol. Chem., 2018, 16, 2591-2601; (c) Y. C. Wang, J. L. Wang, K. S. Burgess, J. W. Zhang, Q. M. Zheng, Y. D. Pu, L. J. Yan and X. B. Chen, RSC Adv., 2018, 8, 5702-5713.

8 (a) K. V. Gothelf and K. A. Jørgensen, Chem. Rev., 1998, 98, 863-909; (b) I. Coldham and R. Hufton, Chem. Rev., 2005, 105, 2765-2809; (c) G. Pandey, P. Banerjee and S. R. Gadre, Chem. Rev., 2006, 106, 4484-4517; (d) S. Lanka, S. Thennarasu and P. T. Perumal, Tetrahedron Lett., 2014, 55, 2585-2588.

9 (a) G. M. Ziarani, R. Moradi and N. Lashgari, Tetrahedron, 2018, 74, 1323-1353; (b) M. Y. Han, J. Y. Jia and W. Wang, Tetrahedron Lett., 2014, 55, 784-794; (c) B. Bdiri, B. J. Zhao and Z. M. Zhou, Tetrahedron: Asymmetry, 2017, 28, 876-899; (d) H. Pellissier, Tetrahedron, 2012, 68, 2197-2232.

10 (a) L. Hong and R. Wang, Adv. Synth. Catal., 2013, 355, 10231052; (b) Y. Arun, G. Bhaskar, C. Balachandran, S. Ignacimuthu and P. T. Perumal, Bioorg. Med. Chem. Lett., 2013, 23, 1839-1845; (c) G. Subramaniyan, R. Raghunathan and M. Nethaji, Tetrahedron, 2002, 58, 9075-9079; (d) R. Jain, K. Sharma and D. Kumar, Tetrahedron Lett., 2012, 53, 1993-1997.

11 (a) A. I. Almansour, R. S. Kumar, N. Arumugam, A. Basiri, Y. Kia, M. A. Ali, M. Farooq and V. Murugaiyah, Molecules, 2015, 20, 2296-2309; (b) A. R. S. Babu and R. Raghunathan, Tetrahedron, 2007, 63, 8010-8016; (c) A. R. S. Babu and R. Raghunathan, Tetrahedron Lett., 2007, 48, 6809-6813; (d) M. Poornachandran, R. Muruganantham and R. Raghunathan, Synth. Commun., 2006, 36, 141-150; (e) M. Poornachandran and R. Raghunathan, Synth. Commun., 2007, 37, 2507-2517.

12 (a) D. S. Allgäuer and H. Mayr, Eur. J. Org. Chem., 2014, 14, 2956-2963; (b) D. S. Allgäuer, P. Mayer and H. Mayr, J. Am. Chem. Soc., 2013, 135, 15216-15224; (c) A. S. Al-Bogami and A. S. El-Ahl, Lett. Org. Chem., 2015, 12, 2-12; (d) A. V. Velikorodov, N. M. Imasheva, A. K. Kuanchalieva and O. Y. Poddubnyi, Russ. J. Org. Chem., 2010, 46, 971-975.

13 (a) L. Wu, J. Sun and C. G. Yan, Org. Biomol. Chem., 2012, 10, 9452-9463; (b) R. Z. Liu, R. G. Shi, J. Sun and C. G. Yan, Org. Chem. Front., 2017, 4, 354-357; (c) J. Sun, G. L. Shen, Y. Huang and C. G. Yan, Sci. Rep., 2017, 7, 41024.

14 (a) I. Fejes, M. Nyerges, A. Szollosy, G. Blasko and L. Toke, Tetrahedron, 2001, 57, 1129-1137; (b) M. Nyerges, L. Gajdics, A. Szollosy and L. Toke, Synlett, 1999, 1, 111-113. 15 (a) Y. Sarra, M. Hamzehloueian, K. Alimohammadi and S. Yeganegi, J. Mol. Struct., 2012, 1030, 168-176; (b) C. Q. Peng, J. W. Ren, J. A. Xiao, H. G. Zhang, H. Yang and Y. M. Luo, Beilstein J. Org. Chem., 2014, 10, 352-360.

16 (a) P. J. Xia, Y. H. Sun, J. A. Xiao, Z. F. Zhou, S. S. Wen, Y. Xiong, G. C. Ou, X. Q. Chen and H. Yang, J. Org. Chem., 2015, 80, 11573-11579; (b) K. Alimohammadi, Y. Sarrafi and B. Rajabpour, C. R. Chim., 2014, 17, 156-163. 